\title{
Comparative Behavior of Ralstonia solanacearum Biovar 2 in Diverse Plant Species
}

\author{
B. Álvarez, J. Vasse, V. Le-Courtois, D. Trigalet-Démery, M. M. López, and A. Trigalet
}

First and fifth authors: Instituto Valenciano de Investigaciones Agrarias (IVIA), Carretera Moncada-Náquera, km 4.5. Moncada, 46113, Valencia, Spain; and second, third, fourth, and sixth authors: Laboratoire des Interactions Plantes Micro-organismes, UMR CNRS/INRA 2594/441, Chemin de Borde Rouge, BP 52627, 31326 Castanet-Tolosan Cedex, France.

Accepted for publication 21 July 2007

\begin{abstract}
Álvarez, B., Vasse, J., Le-Courtois, V., Trigalet-Démery, D., López, M. M., and Trigalet, A. 2008. Comparative behavior of Ralstonia solanacearum biovar 2 in diverse plant species. Phytopathology 98:59-68.

Ralstonia solanacearum causes bacterial wilt in numerous plant species worldwide. Although biovar 2 mostly affects solanaceous crops, identification of new hosts remains a matter of concern since there is still no clear-cut distinction between host and nonhost plants. In this work we provide data based on histological studies on the status of 20 plant species, most of them of potential interest in crop rotation. Plants were watered with a $\beta$-glucuronidase-expressing derivative of $R$. solanacearum

xylem. Depending on whether the xylem was colonized or not, plants were classified as hosts or nonhosts, respectively. Hosts generally affected in a few xylem vessels or occasionally in all xylem bundles were classified as tolerant. These included some cabbage, kidney bean, and rutabaga cultivars, and the weed bittersweet nightshade (Solanum dulcamara). Nonhosts were the cultivars tested of alfalfa, barley, black radish, carrot, celery, colocynth, fennel, fiber flax, field bean, field pea, horseradish, maize, and zucchini. However, barley and maize, though nonhosts, may act as reservoirs for the pathogen. The present work constitutes a basis for further studies on cropping systems in fields where $R$. solanacearum has been detected.
\end{abstract} biovar 2, and after a month of incubation, sections of roots and stems were analyzed to localize the pathogen on surface, in cortex and/or

There are few plant-pathogenic bacteria that affect as many plant species as $R$. solanacearum (24). Currently, its host range encompasses 53 botanical families (21). This soil- and waterborne pathogen goes through the plant roots and colonizes the xylem causing the bacterial wilt disease, which progresses to death after vascular browning and necrosis $(24,38)$. The bacterium is widespread and produces severe economic losses worldwide (9) as many of its hosts are of agricultural interest $(9,21)$. The $R$. solanacearum species complex (13) has traditionally been classified into races and biovars, according to host range and biochemical characteristics, respectively (20).

In Europe, recent epidemics of potato brown rot (browning of potato vascular ring) caused by $R$. solanacearum race (R) 3 biovar (bv) 2 have triggered studies on the epidemiology of this pathogen. R3 bv2 is a group thought to be more adapted to solanaceous crops in temperate climates, though some nonsolanaceous weeds are potential hosts $(21,28,42)$. Because $R$. solanacearum has been recognized as a quarantine organism in the European Union, very stringent control directives have been imposed (2-4). Notably, after an outbreak, there is a minimum 4-year ban on planting host plants as well as regular checks for elimination of weed hosts and volunteer plants. In the United States, R3 bv2 has recently been introduced in ornamental plants, raising concern because of the threat posed to the potato industry (40). Strict security regulations are inflicted since, in the United States, $R$. solanacearum R3 bv2 is considered to be a quarantine pathogen and a select agent of agroterrorism (40).

Corresponding authors: A. Trigalet; E-mail address: andre.trigalet@orange.fr and M. M. López; E-mail address: mlopez@ivia.es

doi:10.1094/PHYTO-98-1-0059

(C) 2008 The American Phytopathological Society
Additional keywords: histological localization.

In the field, special attention has been paid to the identification of $R$. solanacearum hosts that could act as reservoirs during intercropping. For instance, Solanum dulcamara, a common semiaquatic weed inhabiting river banks in Europe, seems to be a shelter for this pathogen and favor its dissemination in river water used for irrigation, playing a role in the persistence and spread of $R$. solanacearum in the environment $(9,11)$.

The host range of the $R$. solanacearum species complex is mainly based upon observation of wilt symptoms in the field, followed by isolation of the pathogen and further inoculation to a susceptible host plant to fulfill Koch's postulates. This approach has long been used to define true hosts of the pathogen as identified by Kelman (24).

In rotation schemes carried out to prevent bacterial wilt, a number of candidates which were referred to as nonhosts often failed to eradicate the pathogen from fields infested with R3 bv2 $(1,14)$. This could possibly be explained by the lack of a clear-cut distinction between host and nonhost plants.

Microscopy-based studies have been published describing different infection processes in susceptible and/or tolerant plants by the pathogen and its nonpathogenic mutants $(5,12,19,44,45)$. Furthermore, histological observations of root infection by the pathogen and further invasion of vascular bundles in the aerial part notably differ in susceptible and tolerant host plants (18, 34). Because the host versus nonhost distinction may lead to conflicting results when applied to potential rotation crops, we believe that this status must be reexamined from a histological, microscopy-based approach of plant colonization by this pathogen.

In this work, a $\beta$-glucuronidase-expressing $R$. solanacearum bv2 was used to determine the localizations of the pathogen in tissues from a series of potential rotation crop candidates. On the basis of light microscopy and bacterial isolation, these plant species were classified as hosts or nonhosts for the bacterium. 
Crops which were classified as nonhosts could be further assessed in open-field experiments to confirm their suitability for rotation schemes in areas where $R$. solanacearum R3 bv2 had been detected.

\section{MATERIALS AND METHODS}

Bacterial strains and growth conditions. The $\beta$-glucuronidase-expressing strain 1.3 derived from $R$. solanacearum strain IPO-1609 (R3 bv2), called IPO-1609-Gus strain 1.3, was used in this study. Strain IPO-1609 was isolated by the Dutch Plant Protection Service from infected potato tubers cv. Bartina in 1995 (PD strain 2763) (43). The uidA gene (37) was introduced into the strain as described by Etchebar et al. (12) for the $R$. solanacearum strain GMI 1,000 (R1 bv3), which was also included in some comparative assays, hereafter referred to as the $\beta$-glucuronidaseexpressing GMI 1,000 strain 9.2. Strains were kept at $-80^{\circ} \mathrm{C}$ in a cryo-preservative medium containing $20 \%$ glycerol. After removal from the freezer, they were plated onto BGT agar (7) or yeast peptone glucose agar (YPGA) (26) and incubated at $30^{\circ} \mathrm{C}$ for 3 days.

Preparation of inocula. Flasks containing BGT liquid medium (7) were inoculated with the bacterial cultures and incubated for $24 \mathrm{~h}$ at $30^{\circ} \mathrm{C}$ on a gyratory incubator shaker $(185 \mathrm{rpm})$. Bacterial suspensions were then adjusted to a concentration between 1.0 to $5.0 \times 10^{8}$ colony forming units $(\mathrm{CFU})$ per milliliter. Inocula were all checked by plating onto BGT agar (7) or YPGA (26) to observe typical smooth colonies after a 3-day incubation at $30^{\circ} \mathrm{C}$. These suspensions were diluted in nonsterilized water for plant inoculations.

Preliminary assays to test the $\beta$-glucuronidase-expressing IPO-1609 strain 1.3. A suspension of the IPO-1609-Gus strain 1.3 was water inoculated in nonsterile peat mix with 155 -weekold tomato plants (Lycopersicon esculentum cv. Roma) susceptible to $R$. solanacearum R3 bv2. Watering was performed twice within a 4-day interval with $150 \mathrm{ml}$ of a $10^{7} \mathrm{CFU} / \mathrm{ml}$ suspension per plant. Five uninoculated plants remained as negative controls. Movement of the target bacteria was followed weekly for 35 days at low, middle, and high stem levels, whose approximate distances from soil were 2 to 10,20 to 30 , and 45 to $55 \mathrm{~cm}$, respectively.

A similar assay with this derivative and the $\beta$-glucuronidaseexpressing GMI 1,000 strain 9.2 was also performed for comparative purposes on groups of six tomato plants cv. Supermarmande. All the assays were done in duplicate.

Evaluated species and growth conditions. Evaluated plants were potato (Solanum tuberosum L. cvs. Désirée and Spunta) as positive controls, the aquatic weed bittersweet nightshade (Solanum dulcamara), and the crops: alfalfa (Medicago sativa cvs. Gea R1 and Symphonie), barley (Hordeum vulgare cv. Cork), black radish (Raphanus sativus cv. Gros Long d'Hiver), cabbage (Brassica oleracea cvs. Quintal d'Alsace and Virtudes), carrot (Daucus carota L. cvs. Nantaise and Tempo), celery (Apium graveolens $\mathrm{cv}$. Istar), colocynth (Citullus colocynthis spp.), curly endive (Cichorium endive cv. Rida Doble de Verano), fennel (Foeniculum vulgare cv. Doux de Florence), fiber flax (Linum spp. cv. Hermès), field bean (Vicia spp. cv. Maya), field pea (Pisum spp. cv. Solara), forage cabbage (Brassica spp. cv. Proteor), horseradish (Armoracia rusticana spp.), kidney bean (Phaseolus vulgaris L. cv. Coco blanc), maize (Zea mays cv. Symphony), rutabaga (Brassica napus nappobrassicus cvs. Champion and Whilemsburger), and zucchini (Cucurbita pepo cv. Virginia).

Axenic potato seedlings were kindly provided by the French Federation for Potato (Paris). For bittersweet nightshade, seed sterilization was that described by Boucher et al. (7). For preliminary assays of several species under axenic conditions, seeds were scarified by immersion in sulfuric acid $(5 \mathrm{~min}$ for barley, fiber flax, and maize, 3 min for carrot and fennel) with intermittent shaking, rinsed in sterile water, and surface sterilized by soaking in sodium hypochlorite (3.6\% of active chlorine) until seed coats were partially removed. Kidney bean seeds were immersed in sodium hypochlorite for $5 \mathrm{~min}$. All seeds were washed three times with sterile water and were aseptically placed on petri dishes containing BGT agar. They were protected from light by aluminum coating and kept in a growth chamber at $24^{\circ} \mathrm{C}$. Germinated seeds were transferred to sterile test tubes by deposition on either (i) stainless steel gauze at the surface of $65 \mathrm{ml}$ of $0.43 \%$ Murashige and Skoog (MS) plant nutrient solution liquid medium as previously described (45) for bittersweet nightshade, fennel, and kidney bean, (ii) the surface of $35 \mathrm{ml}$ of $0.5 \%$ soft agar containing $0.43 \%(\mathrm{wt} / \mathrm{vol})$ of $\mathrm{MS}$ for barley, maize, and potato, or (iii) the surface of $10 \mathrm{~g}$ of either sterilized vermiculite (carrot) or vermiculite mixed with peat mix (fiber flax). The tubes were kept in a growth chamber $\left(16 \mathrm{~h}\right.$ light, $8 \mathrm{~h}$ dark; $\left.24^{\circ} \mathrm{C}\right)$.

For experiments in nonaxenic conditions, plants were grown in peat mix (66\% black and white peat 7:3, 34\% sand, pH 5.8, SC 8 Zaai, Vriezenveen Potgrond BV) in a greenhouse until plants reached 25 to $30 \mathrm{~cm}$ in height. They were then transferred to a growth chamber $\left(16 \mathrm{~h}\right.$ light, $26^{\circ} \mathrm{C} ; 8 \mathrm{~h}$ dark, $\left.22^{\circ} \mathrm{C}\right)$.

Plant inoculations. Small axenic plantlets $(15$ to $20 \mathrm{~cm}$ in height) were inoculated with the $\beta$-glucuronidase-expressing IPO1609 strain 1.3 by aseptically adding to each test tube the appropriate volume (between 0.7 and $6.5 \mathrm{ml}$ ) from the suspension at $10^{8} \mathrm{CFU} / \mathrm{ml}$ to reach a final concentration of $10^{7} \mathrm{CFU} / \mathrm{ml}$ in either liquid solution, soft agar, or vermiculite with or without peat mix. Bacterial suspensions were applied to the lowest part of the plant stem. For peat mix experiments, plants were inoculated with the strain by watering twice at a 4-day interval with $150 \mathrm{ml} /$ plant for all but one plant species or by soaking with $400 \mathrm{ml} /$ plant for bittersweet nightshade. Soaking consisted of a temporary flooding of plant roots in the peat mix (about 1 week), until complete absorption had occurred. Most experiments were conducted with 18 individuals, and repetitions were carried out at least in duplicate. Inoculum concentrations were $10^{7}$ and $10^{6} \mathrm{CFU} / \mathrm{ml}$, respectively, for watering and soaking inoculations. Uninoculated plants were used as negative controls.

At approximately 1 month postinoculation (mpi), each tested plant was cut at root and stem levels, and the peat mix in contact with roots was sampled to recover the bacterium, by the following procedures.

Bacterial isolation, quantification, and identification from plant segments. Stem segments analyzed were 2 to 3 and 4 to $5 \mathrm{~cm}$ long for axenic and nonaxenic plants respectively, except for nonaxenic alfalfa, carrot, and fennel, from which 1- to 2-cm-length fragments were cut from the shoot-root transition region. Segments were all surface sterilized by immersion in a $70 \%$ ethanol solution for 10 to $20 \mathrm{~s}$ and then by drying (axenic plants) or flaming (nonaxenic plants). They were cut into small pieces, covered with sterile water, and incubated at $30^{\circ} \mathrm{C}$ for $24 \mathrm{~h}$. Aliquots were plated onto a modified semiselective agar medium (SMSA), South Africa (10) either by a spiral plate maker (Interscience, Saint Nom la Breteche, France) or according to the surface spread plate technique, and incubated at $30^{\circ} \mathrm{C}$ for 3 days. Colonies were identified by polymerase chain reaction (PCR) using primers OLI 1 and Y2 as described by Seal et al. (36), phcA1 and phcA4 according to Poussier et al. (32), or cooperative PCR using primers OLI 1, OLI 2, and JE 2 as previously described (8).

Root segments analyzed to detect the presence of the pathogen on root surfaces were soaked in sterile water for $1 \mathrm{~h}$ at room temperature. From the macerating liquid the bacterium was isolated on SMSA (32) as indicated for stems and indirect immunofluorescence (IF) was performed with a monoclonal antibody obtained against $R$. solanacearum (5).

Bacterial isolation and identification from peat mix. An appropriate volume of sterile water was added to nonaxenic peat mix in 
contact with plant roots, mixed and incubated without shaking at room temperature for $24 \mathrm{~h}$. Aliquots were plated onto SMSA, and colonies were identified by PCR as mentioned above.

GUS activity assays. Histochemical assays for uidA expression were performed with the root and basal part of the stem. Roots were immersed in a GUS reaction liquid solution $(1.25 \mathrm{mM}$ potassium ferricyanide $0.1 \mathrm{M} ; 1.25 \mathrm{mM}$ potassium ferrocyanide $0.1 \mathrm{M} ; 0.25 \mathrm{mg} / \mathrm{ml}$ 5-bromo-4-chloro-3-indoxyl- $\beta$-D-glucuronide $25 \mathrm{mg} / \mathrm{ml} ; 12.5 \mathrm{mM} \mathrm{KH} \mathrm{PO}_{4}-\mathrm{Na}_{2} \mathrm{HPO}_{4}$ buffer $0.5 \mathrm{M}, \mathrm{pH} 6.8$ ), incubated at $30^{\circ} \mathrm{C}$ for $24 \mathrm{~h}$, and then kept at $4^{\circ} \mathrm{C}$ in sodium cacodylate buffer $0.2 \mathrm{M}$ adjusted to $\mathrm{pH} 7.2$; for nonaxenic plant roots, three previous rinses in sterile water, one in a $70 \%$ ethanol solution and drying were required. The lower parts of stems were cut in longitudinal and thin transverse sections, and placed onto a $0.8 \%$ soft and sterile agar layer containing the GUS reaction solution as described elsewhere (12); for nonaxenic basal parts of stems, a previous short rinse in a $70 \%$ ethanol solution and drying were required. All covered sections were incubated at $30^{\circ} \mathrm{C}$ for $24 \mathrm{~h}$.

Microscopy methods. A Zeiss Axiophot microscope was used to screen root segments of interest and visualize thin longitudinal and transverse sections. Long blue segments (several centimeters) from the root system of all plants tested were observed in bright field microscopy without further staining. Representative colored parts ( 1 to 5) from these segments and occasionally from the basal stem zone were selected and cut into 4 to $5 \mathrm{~mm}$ pieces to be embedded in a 5\% agar solution; after solidification, transverse sections of $150 \mu \mathrm{m}$ were cut with a vibratome (Bio-Rad, Microcut H1200). Semi-thin root and basal stem sections (1 to $1.5 \mu \mathrm{m}$ ) were also obtained after Epson resin embedding with an ultramicrotome (Ultracut, Reichert-Jung) and observed by bright field microscopy after staining, as previously described (45). Pictures were taken with an adapted camera.

M3Z Wild Leitg and Leica MZ 7.5 stereoscopes were used to observe whole roots and sections of lower parts of stems. Color pictures were obtained with an adapted photo system and a digital camera Nikon Coolpix 990 placed on the device objective, respectively. Color pictures of the slides were taken either with a Nikon Coolpix 990 digital camera or a ScanJet 7400 c scanner (Hewlett Packard), at an image resolution of 600 ppi.

\section{RESULTS}

Localization of the $\beta$-glucuronidase-expressing IPO-1609 strain $\mathbf{1 . 3}$ in tomato tissues. Histological localization and isolation revealed a heavy vascular infection of the basal and middle part of tomato stems by $R$. solanacearum strain IPO-1609 expressing GUS in nonaxenic peat mix-grown tomato plants cv. Roma (Table 1). Colonization by the pathogen was observed at 10 days postinoculation (dpi) at the collar level, and at 35 dpi blue color was found in the lowest part of the stems from all analyzed plants, in the middle part from 7 out of 12, and in the higher part from 2 out of 9 tested. Population sizes determined on SMSA at lower parts of stems ranged between $10^{6}$ and $10^{9} \mathrm{CFU} / \mathrm{g}$ dry weight (Table 1). All inoculated tomato plants were positive for the isolation of the bacterium and uidA expression was found in a majority of xylem bundles in each individual tomato plant. Although $\beta$-glucuronidase assays using X-Gluc are not quantitative, an estimated limit of sensitivity of the Gus stain (based on detection of bacteria by dilution plating in tomato plants) would be around $10^{4} \mathrm{CFU} / \mathrm{g}$ dry weight.

Comparative invasiveness between $R$. solanacearum $R 3$ bv2 and $\mathbf{R} 1$ bv3 in tomato tissues. All nonaxenic peat mix-grown tomato plants cv. Supermarmande watered with a suspension of the $\beta$-glucuronidase-expressing GMI 1,000 strain 9.2 (R1 bv3) were completely wilted at $6 \mathrm{dpi}$, whereas the plants inoculated with IPO-1609-Gus strain 1.3 (R3 bv2) started to show disease symptoms at $8 \mathrm{dpi}$. Localization of bacteria at collar level at this time revealed that the GMI 1,000 derivative had strongly colonized the four bundles of xylem in all tested plants (Fig. 1A), while comparably the $\beta$-glucuronidase-expressing IPO-1609 was not detected in all bundles of wilted plants (Fig. 1B).

Localization of the $\beta$-glucuronidase-expressing IPO-1609 strain 1.3 in potato tissues. Colonization by the pathogen was first assessed in potato plants, cvs. Désirée and Spunta, under axenic conditions in soft agar. In cv. Désirée, at $1 \mathrm{mpi}$ inoculated bacteria had entered through the axils of lateral emerging roots and extremities of stolons (Fig. 1C). Blue staining in xylem vessels was localized at the collar level in five out of six analyzed plants. The invaded vessels mostly belonged to the same xylem bundle out of the four commonly present in potato stems, and one out of six plants showed the inner cortex colonized next to the invaded vessels (not shown). In cv. Spunta, at 1 mpi the bacterium was located in the root system at root extremities and lateral root emerging sites, and by 2 mpi a majority of xylem vessels were invaded, as shown in Figure 1D. Xylem vessels partially or even totally filled with bacterial cells were also observed (Fig. 1E). For both cultivars, most of the plants remained symptomless during the postinoculation period (1 mpi for Désirée, 2 mpi for Spunta), with some of them showing partial wilting. Under nonaxenic con-

TABLE 1. Detection of the $\beta$-glucuronidase-expressing IPO-1609 strain 1.3 of Ralstonia solanacearum R3 bv2 in tomato plants cv. Roma at 35 days postinoculation

\begin{tabular}{|c|c|c|c|c|c|c|}
\hline \multirow[b]{2}{*}{ Plant number } & \multicolumn{3}{|c|}{ Histological localization in stem (xylem) } & \multicolumn{3}{|c|}{ Isolation from stem on semiselective agar medium (CFU/g dry weight) } \\
\hline & Lower $(2-5 \mathrm{~cm})^{\mathrm{a}}$ & Middle $(20-25 \mathrm{~cm})$ & Upper $(45-50 \mathrm{~cm})$ & Lower $(5-10 \mathrm{~cm})$ & Middle $(25-30 \mathrm{~cm})$ & Upper $(50-55 \mathrm{~cm})$ \\
\hline 1 & $++^{\mathrm{b}}$ & $+^{\mathrm{c}}$ & + & $7.6 \times 10^{9}$ & $>1.4 \times 10^{7}$ & $>5.6 \times 10^{7}$ \\
\hline 2 & ++ & + & $-{ }^{d}$ & $3.1 \times 10^{9}$ & $>1.4 \times 10^{6}$ & - \\
\hline 4 & + & - & - & $>1.2 \times 10^{7}$ & - & - \\
\hline 5 & ++ & + & - & $4.6 \times 10^{9}$ & $>1.4 \times 10^{6}$ & - \\
\hline 6 & ++ & ++ & $\mathrm{nt}^{\mathrm{e}}$ & $7.7 \times 10^{9}$ & $6.8 \times 10^{9}$ & nt \\
\hline 10 & + & + & + & $7.5 \times 10^{9}$ & $>1.4 \times 10^{7}$ & $>5.6 \times 10^{6}$ \\
\hline 11 & ++ & ++ & nt & $4.8 \times 10^{9}$ & $1.5 \times 10^{9}$ & $\mathrm{nt}$ \\
\hline 12 & + & ++ & $\mathrm{nt}$ & $>1.2 \times 10^{7}$ & $6.0 \times 10^{9}$ & nt \\
\hline Control & - & - & - & - & - & - \\
\hline
\end{tabular}

a Approximate height from soil level to the analyzed stem fragment.

${ }^{\mathrm{b}}$ One to four xylem bundles stained.

${ }^{c}$ One to ten groups of few vessels of xylem stained.

${ }^{\mathrm{d}}$ Undetected.

e Not tested. 

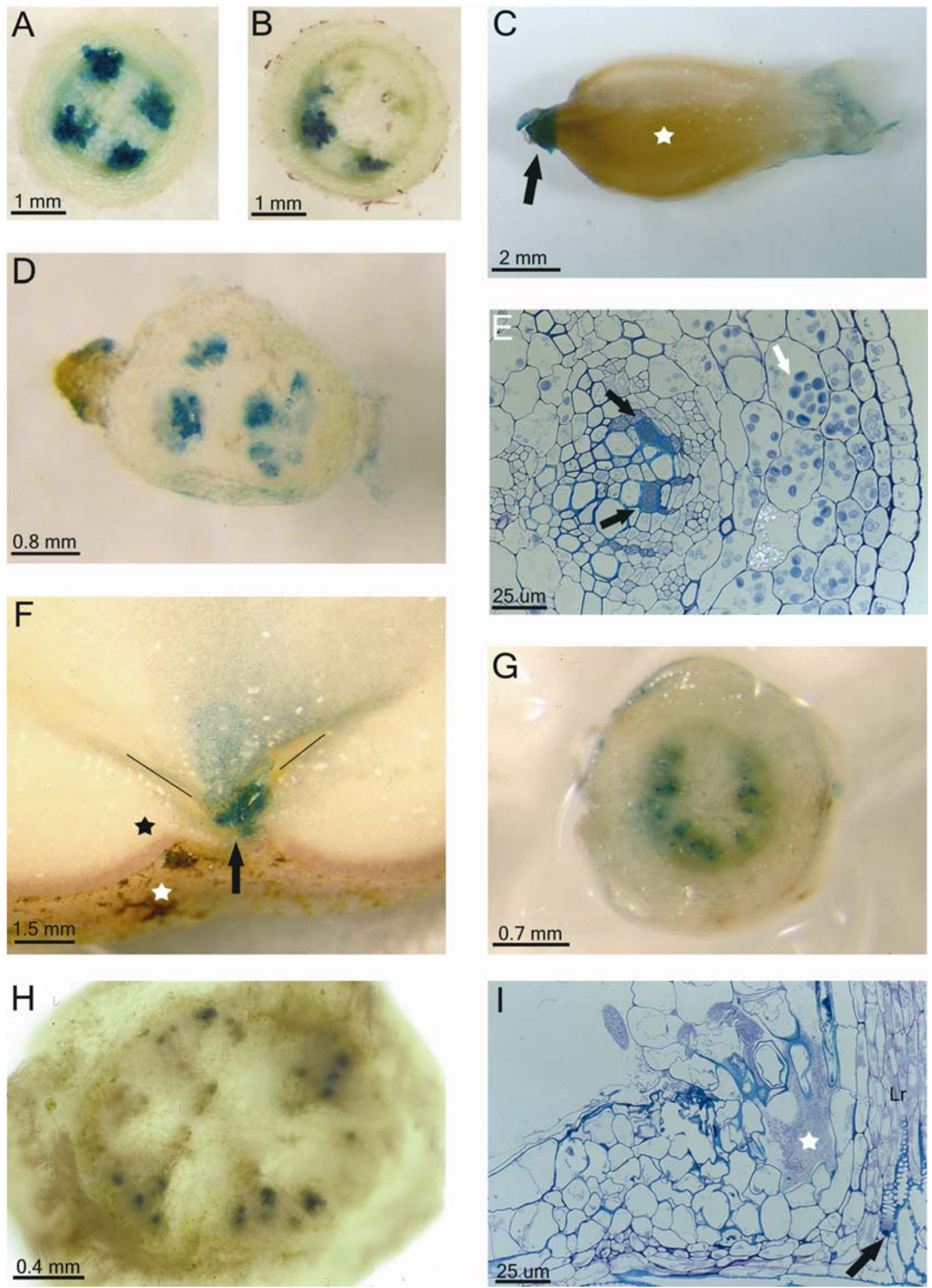

Fig. 1. Light microscopy of infection and colonization of plant species by $\beta$-glucuronidase-expressing derivatives of Ralstonia. solanacearum. Plants were grown in nonaxenic peat mix (A, B, F, G, K, L, N, O, P, Q, and $\mathbf{R})$ or in axenic conditions ( $\mathbf{C}, \mathbf{D}, \mathbf{E}, \mathbf{S}$, and $\mathbf{T}$ in soft agar; $\mathbf{H}, \mathbf{I}, \mathbf{J}, \mathbf{M}$ in liquid solution). Pictures refer to the $\beta$-glucuronidase-expressing IPO-1609 strain 1.3 of $R$. solanacearum R3 bv2, unless otherwise mentioned. A and B, Vascular colonization of tomato hypocotyls (cv. Supermarmande) by derivatives of GMI 1,000 (R1 bv3) and IPO-1609 (R3 bv2), respectively. C, Infection (black arrow) of a young tuber (white star) at the end of a stolon. D, Invasion of vascular system of a potato stem at 2 months postinoculation. E, Semi-thin section in the potato stem. Note target bacteria in the xylem vessels (black arrows) and abundant presence of amyloplast (white arrow). F, Infection (black arrow) of a potato tuber bud and vascular invasion (black lines) of the tuber stolon meristem in a longitudinal cut (black star) of the tuber. The white star indicates the epidermis of the tuber. G, Transverse cut of a potato stolon showing vascular invasion. H, Xylem colonization in bittersweet nightshade collar. I, Semi-thin transverse cut of bittersweet nightshade at a root crack of a secondary root with an abundant, intercellular cortical infection (white star) and vascular invasion (black arrow); Lr, longitudinal root. J, Semi-thin longitudinal section showing intercellular infection of inner cortex at a root tip of bittersweet nightshade (white stars). K, Adsorption on some external tissues in alfalfa. L, Adsorption to the external surface in longitudinal and transverse sections of lower parts of stems in barley. M, Invasion of vascular tissues in kidney bean (white asterisks). N, Vascular colonization of central cylinder in cabbage (white asterisk). O, Semi-thin section from an infected cabbage stem showing metaxylem colonization (white asterisks). P, Q, R, Adsorption on some external tissues in carrot, fennel, and fiber flax, respectively. S, Transverse semi-thin section of maize root with intercellular infection of the inner root cortex (white star), proximal to an emergent meristem (m) of a lateral root, and the endodermis (e). T, Large infection of cortical tissues in maize by derivative of strain GMI 1,000. Target bacteria were visualized in plant tissues either by $\beta$-glucuronidase activity in handmade plant sections $(\mathbf{A}, \mathbf{B}, \mathbf{C}, \mathbf{F}, \mathbf{G}, \mathbf{H}, \mathbf{K}, \mathbf{L}, \mathbf{N}, \mathbf{P}, \mathbf{Q}$, and $\mathbf{R})$, sections cut with a vibratome (D, M, and T) or poststaining with methylene and toluidine blue in semi-thin sections $(\mathbf{E}, \mathbf{I}, \mathbf{J}, \mathbf{O}$, and $\mathbf{S})$. Different scale bars are indicated on each picture. 
Fig. 1. (continued from preceding page)
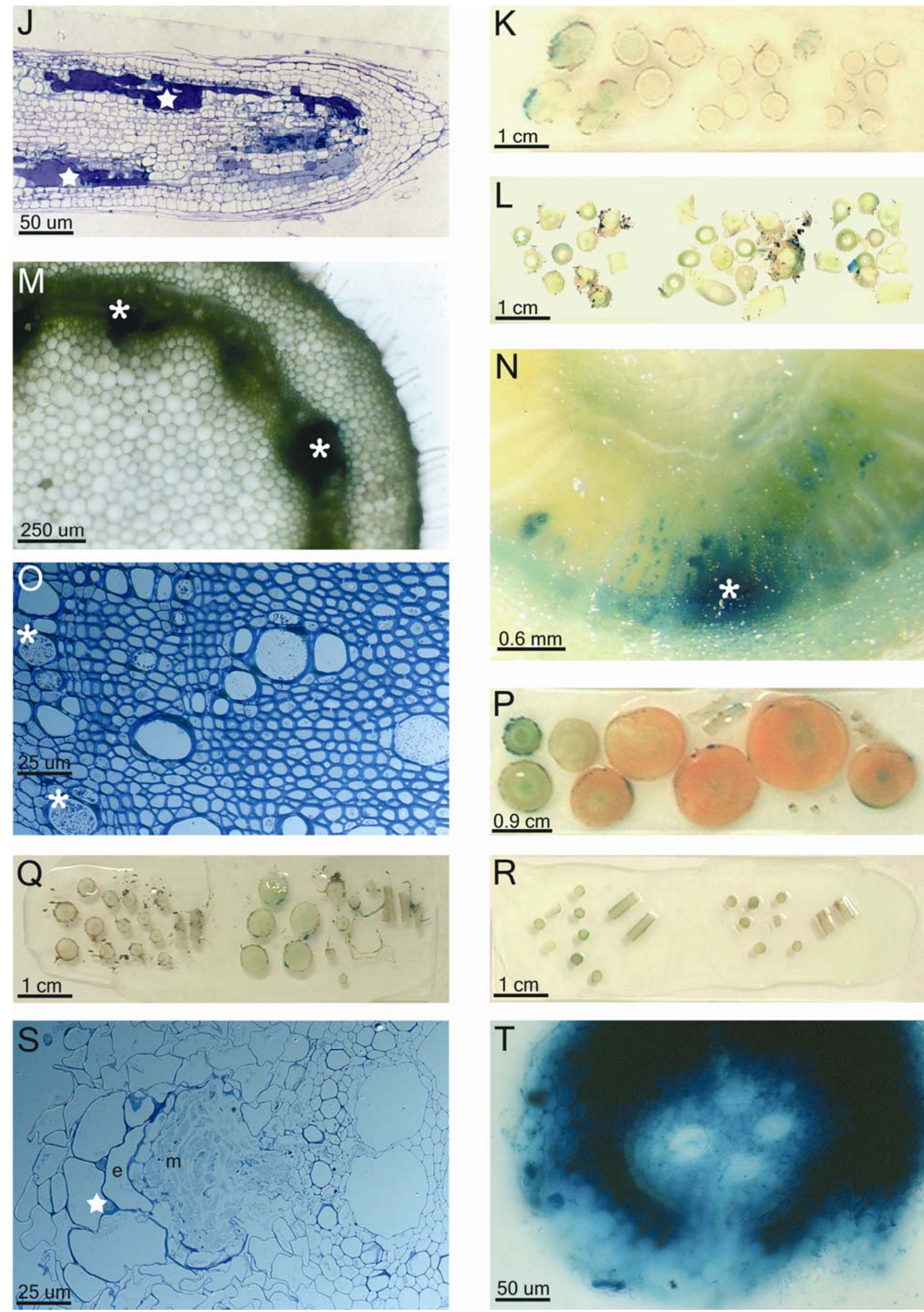

$\mathrm{N}$

$\underline{0.6 \mathrm{~mm}}$
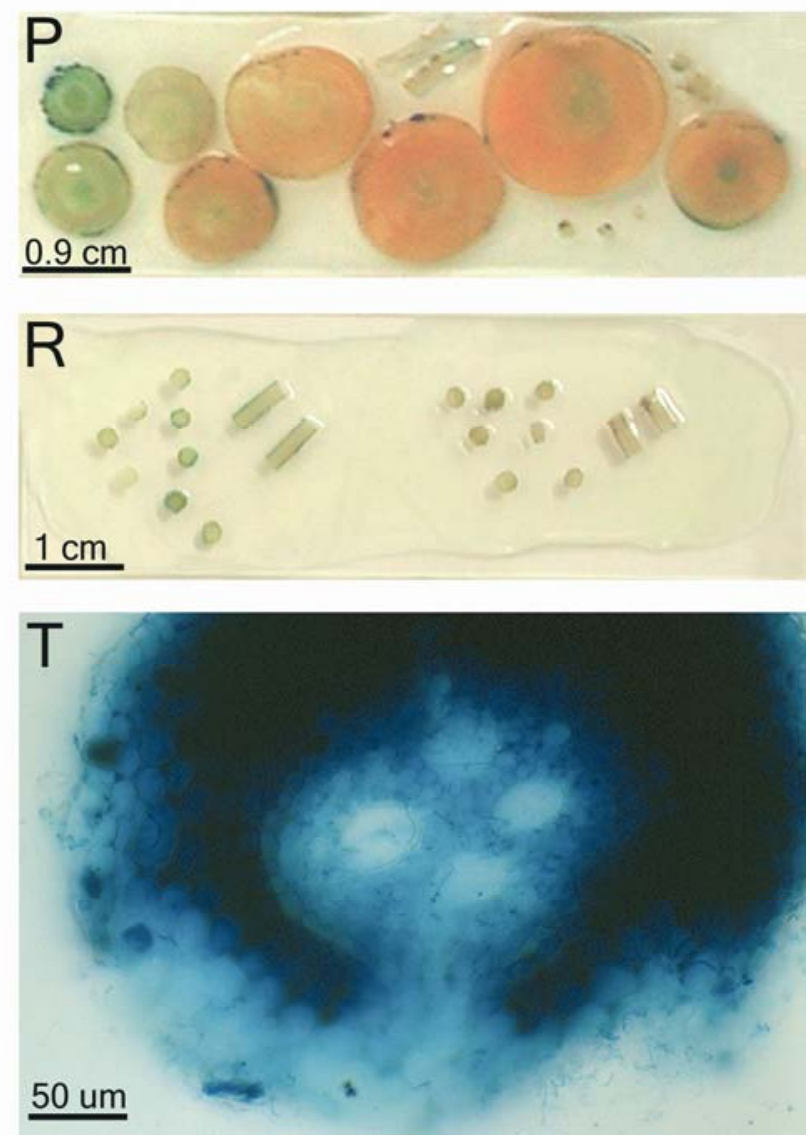
ditions, peat mix-grown potato plants cv. Désirée started to show symptoms after 5 weeks postinoculation and by $2 \mathrm{mpi}$ were already wilted. They had the central cylinders of primary and secondary roots heavily colonized at $2 \mathrm{mpi}$. In all potato tubers, eyes, heel ends, and stolons were also strongly invaded (Fig. 1F and $\mathrm{G}$ ), and thick bacterial ooze was observed in vascular rings. The route by which the pathogen can penetrate the vascular tissues of tuber via the eye from outside is clearly illustrated in Figure 1F. IPO-1609-Gus also concentrated at the stolon/tuber junction in almost all tubers tested (not shown).

Localization of the $\beta$-glucuronidase-expressing IPO-1609 strain 1.3 in bittersweet nightshade tissues. Transverse sections of collars of bittersweet nightshade plants grown under axenic conditions in MS liquid solution, showed presence of bacteria in small groups of xylem vessels scattered throughout the bundles in all 8 plants processed (Fig. 1H). Presence of bacterial cells in these vessels was further confirmed by microscopic visualization of transverse semi-thin sections, which also enabled us to observe tyloses in vascular tissues (not shown). Likewise, observation of longitudinal and transverse semi-thin sections of roots revealed the presence of bacterial cells in the cortex and xylem areas (Fig. $1 \mathrm{I}$ and $\mathrm{J}$ ), but isolation of the $\beta$-glucuronidase-expressing IPO1609 from stems was negative in all analyzed individuals. From nonaxenic peat mix-grown plants, the collar sections embedded in the GUS soft agar displayed an uidA expression in the xylem vessels in 3 out of the 12 exposed plants. The bacterium was isolated from the stem of 2 out of 3 plants, accounting for $9 \times$ $10^{5} \mathrm{CFU} / \mathrm{g}$ dry weight.

Localization of the $\beta$-glucuronidase-expressing IPO-1609 strain 1.3 in other plant species. Alfalfa. For cv. Gea R1 in the nonaxenic peat mix-grown plants, there was no GUS activity detected inside plant tissues (Fig. 1K). Bacterial isolations from the shoot-root transition region were also negative (Table 2). For cv. Symphonie in the nonaxenic peat mix-grown plants, no blue staining was observed in either cortex or xylem and isolations were negative, although bacteria were detected on root surfaces (Table 2).

Barley. For cv. Cork under axenic conditions in soft agar, 3 out of the 10 inoculated barley plants in two separate assays contained $R$. solanacearum (data not shown). Preliminary experiments were also performed in soft agar by flooding the lowest part of plant stems with a $10^{8} \mathrm{CFU} / \mathrm{ml}$ inoculum. Transverse sections from these flooded stems displayed intense blue staining between the leaves forming the sheath of the plant and isolations of the bacterium from these flooded stems were frequently positive (data not shown). From the nonaxenic peat mix-grown plants, transverse sections from all upper parts of root systems and basal part of stems showed a blue staining on the surface, but never in the cortex or xylem (Fig. 1L). Isolations from stems were mostly negative, except for a few individuals, for which positive isolation could be correlated with external presence of the IPO-1609-Gus in the lower parts of the stem (Table 2).

Bean (field bean). For cv. Maya in nonaxenic peat mix-grown plants, the labeled bacterium was detected on the root surface in 11 out of 36 inoculated plants. The cortex area was infected in less than half of these individuals, but this invasion was not observed in upper levels of the plant, whereas xylem tissues were never colonized by the IPO-1609-Gus. Isolations from plant stems correlated with the internal presence of the pathogen in the plant cortex (Table 2).

Bean (kidney bean). For cv. Coco blanc, under axenic conditions in MS liquid solution, almost all transverse sections from roots showed a specific blue staining in vascular parenchyma. At the collar level, intense GUS activity was observed in the cortex and in xylem vessels all around the vascular ring in 10 out of the 14 inoculated plants (Fig. 1M), and the bacterium was isolated from stems in 12 of them (data not shown). From the nonaxenic peat mix-grown plants, transverse sections embedded in GUS reactive agar revealed blue staining in xylem vessels, and isolation was positive from 1 out of the 38 inoculated plants, accounting for $1.1 \times 10^{2} \mathrm{CFU} / \mathrm{g}$ dry weight.

Black radish. For cv. Gros Long d'Hiver, in the nonaxenic peat mix-grown plants, the labeled bacterium was present on the root surface and in the cortex at root level for 4 of 36 plants, but was not detected in the majority. No blue staining was observed in the cortex at the lower stem level, or in the xylem regardless of the plant level. Isolations were positive only from the four plants (Table 2).

Cabbage. For cv. Quintal d'Alsace, from the nonaxenic peat mix-grown plants, the pathogen was always found on root surface in all plants. No blue staining was observed neither in the cortex nor in the xylem at root level, in contrast to the lower part of stem, which was stained in the majority of the individuals. Isolations from these stems were all positive (Table 2). For cv. Virtudes, from the nonaxenic peat mix-grown plants, uidA-expression was observed in some xylem vessels of the lower part of the stem of three individuals out of the 72 plants analyzed (Fig. 1N). The presence of the bacterium was further confirmed in xylem vessels from semi-thin transverse sections (Fig. 1O). Isolations from stem segments were negative in all analyzed plants (Table 2).

Cabbage (forage cabbage). For cv. Proteor, from nonaxenic peat mix-grown plants, all the 36 inoculated individuals showed presence of the $\beta$-glucuronidase-expressing derivative on root surfaces and inner plant tissues (i.e., cortex and xylem at root and lower stem levels). Isolations from stems were positive in all plants tested (Table 2).

Carrot. For cv. Nantaise, under axenic conditions in vermiculite, the analyzed plants did not develop a taproot system and GUS analysis of the small roots for the inoculated 9 plants only showed adsorption on the surface in a limited number of root tips and some extremities of recently emerged secondary roots, which revealed the presence of the pathogen in cortical tissues. In the lower part of the stems, no colonization of cortex or xylem was ever observed (data not shown). From the nonaxenic peat mixgrown plants, blue staining was only noticed on the epidermis of the shoot-root transition region, tuberous root and emerging lateral roots (Fig. 1P). Isolations were negative in all the tested plants (Table 2). The taproots collected from inoculated plants did not differ in size with respect to those from the uninoculated plants. For cv. Tempo, from nonaxenic peat mix-grown plants, no specific blue staining was ever observed in inner or outer plant tissues, in all the 36 analyzed plants (Table 2).

Celery. For cv. Istar, in nonaxenic peat mix-grown plants, there was no uidA expression and isolations were negative from the outer and inner tissues of all 87 tested plants (Table 2).

Colocynth. In nonaxenic peat mix-grown plants, no blue staining was ever observed in tissues of plant sections and isolations were negative for the 36 inoculated plants (Table 2).

Curly endive. For cv. Rida Doble de Verano, in nonaxenic peat mix-grown plants, there was a superficial adsorption on the root systems by the IPO-1609-Gus in all inoculated plants. The roots were frequently invaded in the cortical tissues, although the bacterium was not detected in the xylem. At the lowest stem level, a localized blue staining appeared in both, cortex and xylem, for 18 out of 36 plants. Isolations were positive from the stem of all the 36 individuals (Table 2).

Fennel. For cv. Doux de Florence, under axenic conditions in MS liquid solution, longitudinal and transverse sections of the whole small root system of the nine inoculated plants revealed the presence of uidA-expressing bacteria in the pericycle and cortex areas, respectively (data not shown). All isolations were negative from the shoot-root transition region. From the 23 nonaxenic peat mix-grown plants, no uidA expression in the inner plant tissues was observed (Fig. 1Q). Isolations were negative in all the plants (Table 2). The taproots collected from the inoculated plants did 
not differ in size with respect to those from the uninoculated plants.

Fiber flax. For cv. Hermès, under axenic conditions in vermiculite with peat mix, transverse sections at collar level did not show any specific GUS activity in plant tissues, although isolation was positive for one out of eight inoculated individuals (data not shown). From the nonaxenic peat mix-grown plants, no blue staining and no bacteria were obtained from the majority of the 82 individuals tested (Fig. 1R). Only in four of them, positive isola- tions were correlated with external contamination following casual splashing of the bacterium onto a rough stem surface (Table 2).

Field pea. For cv. Solara, from the nonaxenic peat mix-grown plants, 11 out of the 36 individuals were positive for the presence of the IPO-1609-Gus on root surfaces and a limited cortex infection was detectable in some root systems without any subsequent xylem invasion. No colonization was observed in the upper levels of the plants, either in the cortex tissues or xylem bundles.

TABLE 2. Detection of the $\beta$-glucuronidase-expressing IPO-1609 strain 1.3 of Ralstonia solanacearum $\mathrm{R} 3$ bv2 in plants grown in nonaxenic peat mix ${ }^{\mathrm{a}}$

\begin{tabular}{|c|c|c|c|c|c|c|c|}
\hline \multirow[b]{3}{*}{ Plant species and cultivar } & \multicolumn{5}{|c|}{ Histological localization $^{b}$} & \multirow{3}{*}{$\frac{\text { Isolation }^{\mathrm{c}}}{\text { Stems }}$} & \multirow{3}{*}{$\begin{array}{c}\text { Plant status } \\
\text { (assays in peat mix }\end{array}$} \\
\hline & \multicolumn{3}{|c|}{ Roots } & \multicolumn{2}{|c|}{ Lower part of stems } & & \\
\hline & Surface $^{d}$ & Cortex & Xylem & Cortex & Xylem & & \\
\hline \multirow[t]{2}{*}{ Alfalfa cv. Gea R1 } & $0 / 19$ & $\mathrm{nt}^{\mathrm{e}}$ & nt & $0 / 19$ & $0 / 19$ & $0 / 19$ & Nonhost \\
\hline & $0 / 23$ & $\mathrm{nt}$ & nt & $0 / 23$ & $0 / 23$ & $0 / 23$ & \\
\hline \multirow[t]{2}{*}{ Alfalfa cv. Symphonie } & $6 / 18$ & $0 / 18$ & $0 / 18$ & $0 / 18$ & $0 / 18$ & $0 / 18$ & Nonhost \\
\hline & $8 / 18$ & $0 / 18$ & $0 / 18$ & $0 / 18$ & $0 / 18$ & $0 / 18$ & \\
\hline \multirow[t]{4}{*}{ Barley cv. Cork } & $0 / 15$ & nt & nt & $0 / 15$ & $0 / 15$ & $0 / 15$ & Nonhost \\
\hline & $\mathrm{nt} /$ soilt $^{\mathrm{f}}$ & $\mathrm{nt}$ & $\mathrm{nt}$ & $0 / 17$ & $0 / 17$ & $0 / 17$ & \\
\hline & $0 / 18$ & $0 / 18$ & $0 / 18$ & $0 / 18$ & $0 / 18$ & $0 / 18$ & \\
\hline & $3 / 18$ & $0 / 18$ & $0 / 18$ & $0 / 18$ & $0 / 18$ & $3 / 18$ & \\
\hline \multirow[t]{2}{*}{ Bean (field bean) cv. Maya } & $6 / 18$ & $3 / 18$ & $0 / 18$ & $0 / 18$ & $0 / 18$ & $3 / 18$ & Nonhost \\
\hline & $5 / 18$ & $2 / 18$ & $0 / 18$ & $0 / 18$ & $0 / 18$ & $2 / 18$ & \\
\hline \multirow[t]{2}{*}{ Bean (kidney bean) cv. Coco blanc } & $0 / 18$ & $0 / 18$ & $0 / 18$ & $0 / 18$ & $0 / 18$ & $0 / 18$ & Tolerant host \\
\hline & $0 / 20$ & nt & nt & $1 / 20$ & $1 / 20$ & $1 / 20$ & \\
\hline \multirow[t]{2}{*}{ Black radish cv. Gros Long d'Hiver } & $2 / 18$ & $2 / 18$ & $0 / 18$ & $0 / 18$ & $0 / 18$ & $2 / 18$ & Nonhost \\
\hline & $2 / 18$ & $2 / 18$ & $0 / 18$ & $0 / 18$ & $0 / 18$ & $2 / 18$ & \\
\hline \multirow[t]{2}{*}{ Cabbage cv. Quintal d'Alsace } & $18 / 18$ & $0 / 18$ & $0 / 18$ & $12 / 18$ & $12 / 18$ & $18 / 18$ & Susceptible host \\
\hline & $18 / 18$ & $0 / 18$ & $0 / 18$ & $15 / 18$ & $15 / 18$ & $18 / 18$ & \\
\hline \multirow[t]{4}{*}{ Cabbage cv. Virtudes } & nt/soil+ & $0 / 18$ & $0 / 18$ & $1 / 18$ & $3 / 18$ & $0 / 18$ & Tolerant host \\
\hline & nt & $0 / 18$ & $0 / 18$ & $0 / 18$ & $0 / 18$ & $0 / 18$ & \\
\hline & $0 / 18$ & $0 / 18$ & $0 / 18$ & $0 / 18$ & $0 / 18$ & $0 / 18$ & \\
\hline & $0 / 18$ & $0 / 18$ & $0 / 18$ & $0 / 18$ & $0 / 18$ & $0 / 18$ & \\
\hline \multirow[t]{2}{*}{ Cabbage (forage cabbage) cv. Proteor } & $18 / 18$ & $18 / 18$ & $18 / 18$ & $18 / 18$ & $18 / 18$ & $18 / 18$ & Susceptible host \\
\hline & $18 / 18$ & $18 / 18$ & $18 / 18$ & $18 / 18$ & $18 / 18$ & $18 / 18$ & \\
\hline \multirow[t]{2}{*}{ Carrot cv. Nantaise } & nt/soil+ & $0 / 13$ & $0 / 13$ & $0 / 13$ & $0 / 13$ & $0 / 13$ & Nonhost \\
\hline & $0 / 11$ & $0 / 11$ & $0 / 11$ & $0 / 11$ & $0 / 11$ & $0 / 11$ & \\
\hline \multirow[t]{2}{*}{ Carrot cv. Tempo } & $0 / 18$ & $0 / 18$ & $0 / 18$ & $0 / 18$ & $0 / 18$ & $0 / 18$ & Nonhost \\
\hline & $0 / 18$ & $0 / 18$ & $0 / 18$ & $0 / 18$ & $0 / 18$ & $0 / 18$ & \\
\hline Celery cv. Istar & nt/soil+ & $0 / 20$ & $0 / 20$ & $0 / 20$ & $0 / 20$ & $0 / 20$ & Nonhost \\
\hline & $0 / 13$ & nt & nt & nt & nt & $0 / 13$ & \\
\hline & $0 / 18$ & nt & nt & $0 / 6$ & $0 / 6$ & $0 / 18$ & \\
\hline & $0 / 18$ & $0 / 18$ & $0 / 18$ & $0 / 18$ & $0 / 18$ & $0 / 18$ & \\
\hline & $0 / 18$ & $0 / 18$ & $0 / 18$ & $0 / 18$ & $0 / 18$ & $0 / 18$ & \\
\hline Colocynth & $0 / 18$ & $0 / 18$ & $0 / 18$ & $0 / 18$ & $0 / 18$ & $0 / 18$ & Nonhost \\
\hline & $0 / 18$ & $0 / 18$ & $0 / 18$ & $0 / 18$ & $0 / 18$ & $0 / 18$ & \\
\hline Curly endive cv. Rida Doble de Verano & $18 / 18$ & $12 / 18$ & $0 / 18$ & $9 / 18$ & $9 / 18$ & $18 / 18$ & Susceptible host \\
\hline & $18 / 18$ & $12 / 18$ & $0 / 18$ & $9 / 18$ & $9 / 18$ & $18 / 18$ & \\
\hline Fennel cv. Doux de Florence & nt/soil+ & $0 / 13$ & $0 / 13$ & $0 / 13$ & $0 / 13$ & $0 / 13$ & Nonhost \\
\hline & $0 / 10$ & $0 / 10$ & $0 / 10$ & $0 / 10$ & $0 / 10$ & $0 / 10$ & \\
\hline Fiber flax cv. Hermès & $0 / 23$ & nt & nt & $0 / 23$ & $0 / 23$ & $0 / 23$ & Nonhost \\
\hline & nt/soil+ & nt & nt & $0 / 23$ & $0 / 23$ & $0 / 23$ & \\
\hline & $2 / 18$ & $0 / 18$ & $0 / 18$ & $0 / 18$ & $0 / 18$ & $2 / 18$ & \\
\hline & $2 / 18$ & $0 / 18$ & $0 / 18$ & $0 / 18$ & $0 / 18$ & $2 / 18$ & \\
\hline Field pea cv. Solara & $6 / 18$ & $2 / 18$ & $0 / 18$ & $0 / 18$ & $0 / 18$ & $2 / 18$ & Nonhost \\
\hline & $5 / 18$ & $1 / 18$ & $0 / 18$ & $0 / 18$ & $0 / 18$ & $1 / 18$ & \\
\hline Horseradish & $3 / 18$ & $1 / 18$ & $0 / 18$ & $0 / 18$ & $0 / 18$ & $3 / 18$ & Nonhost \\
\hline & $3 / 18$ & $0 / 18$ & $0 / 18$ & $0 / 18$ & $0 / 18$ & $3 / 18$ & \\
\hline Maize cv. Symphony & nt & $0 / 17$ & $0 / 17$ & $0 / 17$ & $0 / 17$ & $0 / 17$ & Nonhost \\
\hline & nt & $0 / 18$ & $0 / 18$ & $0 / 18$ & $0 / 18$ & $0 / 18$ & \\
\hline & nt/soil+ & $0 / 20$ & $0 / 20$ & $0 / 20$ & $0 / 20$ & $1 / 20$ & \\
\hline Rutabaga cv. Champion & $12 / 18$ & $12 / 18$ & $3 / 18$ & $0 / 18$ & $3 / 18$ & nt & Tolerant host \\
\hline & $12 / 18$ & $12 / 18$ & $3 / 18$ & $0 / 18$ & $3 / 18$ & nt & \\
\hline Rutabaga cv. Whilemsburger & $12 / 18$ & $12 / 18$ & $1 / 18$ & $0 / 18$ & $1 / 18$ & $0 / 18$ & Tolerant host \\
\hline & $12 / 18$ & $12 / 18$ & $2 / 18$ & $0 / 18$ & $2 / 18$ & $0 / 18$ & \\
\hline Zucchini cv. Virginia & $1 / 18$ & $0 / 18$ & $0 / 18$ & $0 / 18$ & $0 / 18$ & $1 / 18$ & Nonhost \\
\hline & $2 / 18$ & $0 / 18$ & $0 / 18$ & $0 / 18$ & $0 / 18$ & $2 / 18$ & \\
\hline
\end{tabular}

${ }^{a}$ Results from different assays are indicated in different lines for each species and cultivar.

b Number of plants with $R$. solanacearum detected by uidA expression per number of analyzed plants.

c Number of plants with $R$. solanacearum isolated from middle part of stems per number of analyzed plants.

${ }^{\mathrm{d}}$ Number of plants with $R$. solanacearum detected by immunofluorescence on root surface per number of analyzed plants.

e Not tested.

${ }^{\mathrm{f}}$ Not tested on roots but positive in peat mix, as determined by isolation on semiselective agar medium and polymerase chain reaction of the colonies. 
Isolations were positive from all the analyzed individuals with an infected cortex (Table 2).

Horseradish. In the nonaxenic peat mix-grown plants, a few root systems from inoculated individuals exhibited an external contamination by the bacterium, but only one of them was invaded in the cortical area, although this infection was not observed in upper levels of the plant. Xylem vessels were never colonized, regardless of the plant level analyzed. Positive isolations in 6 out of the 36 plants were linked to the presence of the pathogen on the root surface and cortex areas (Table 2).

Maize. For cv. Symphony, under axenic conditions in soft agar, microscopy of the transverse semi-thin sections of all plant roots showed small, intercellular infection pockets in the cortex, with a slight colonization of the cortical intercellular spaces by bacterial cells (Fig. 1S). Transverse sections of the lower part of stems did not show any specific GUS activity in inner plant tissues, although the bacterium was isolated from 2 out of the 15 inoculated individuals (data not shown). From the nonaxenic peat mixgrown plants, a blue staining was only observed on the surface of all maize root systems and lower part of stems, while no uidA expression was ever detectable in the transverse sections of the roots and lower plate. Isolations of the pathogen from middle part of the stem were negative for 54 out of the 55 inoculated plants (Table 2). The positive one was correlated with presence of the bacterium between the leaves of the sheath. A similar assay carried out with the $\beta$-glucuronidase-expressing GMI 1,000 strain 9.2 in axenic maize plants grown in soft agar (data not shown) revealed a massive intercellular invasion of cortical tissues, which were particularly highly stained (Fig. 1T).

Rutabaga. For cv. Champion, the IPO-1609-Gus was detected in root epidermal and cortical tissues of 24 out of 36 inoculated plants grown in nonaxenic peat mix, and in xylem of roots and the lower part of stems in only six of them (Table 2). For cv. Whilemsburger, most of the inoculated nonaxenic peat mix-grown plants showed adsorption on the root surface and infection in the root cortex, but only a few of them showed colonization of vascular tissues in the roots. Few plants revealed an invaded xylem at the lower part of the stem. Isolations were negative in all the 36 plants analyzed (Table 2).

Zucchini. For cv. Virginia, from the nonaxenic peat mix-grown plants, the labeled bacterium was detected superficially on root systems in a small number of the inoculated individuals, but no infection and invasion of the inner plant tissues occurred, at any plant level. Positive isolations of the IPO-1609-Gus from the stem were attributed to external contamination (Table 2).

\section{DISCUSSION}

We performed histological analyses to describe the localization of $R$. solanacearum $\mathrm{R} 3$ bv 2 in various root and/or stem tissues from diverse plants. An accurate interpretation can be ascertained if enough plants are used, which will help to differentiate between true and putative host plants.

Some preliminary assays were carried out under axenic conditions in test tubes with barley, carrot, fennel, fiber flax, kidney bean, and maize, in order to compare results with those obtained from the nonaxenic peat mix-grown plants. In both types of experiments, bacteria were generally located in the same zones with no significant differences in barley and fiber flax. However, under axenic conditions, kidney bean plants were more frequently and intensely colonized than in nonaxenic experiments, and roots of maize, carrot, and fennel were only colonized in axenic and never in nonaxenic conditions. Some reasons that may help to explain the differences are (i) the lack of indigenous microbiota prevents competition and/or predation events, reported to occur in natural soils $(16,35)$, (ii) soluble plant factors that favor bacterial growth are more easily accessible to the bacterium in liquid MS or in soft agar than in peat mix, (iii) the weaker development of axenic roots in comparison with roots grown in peat mix, and (iv) $R$. solanacearum was essentially growing in co-culture with the plants in MS liquid solution or in soft agar. Humidity was extremely high, which strongly favored the bacterium and may have permitted it to survive as an epiphyte or endophyte on plants, even though it could not do so under field conditions. Moreover, axenic liquid culture seems to facilitate infection of intercellular spaces of root cortex, boosting disease development (45). On the whole, these conditions might mimic the status encountered in temporary swampy areas in the lowest part of cultivated fields, where the disease first develops. Consequently, in our experiments using a great many species, we mainly focused on peat mix-grown plant assays, as these might correlate better with field conditions, in the absence of temporary excess of water.

We used tomato and potato plants as a control for our methodology. In tomato plants cv. Roma, intense invasion of xylem bundles by the IPO-1609-Gus strain 1.3 was visible at the collar level after 1 week postinoculation and was generalized in all plants by 1 month. Histological localization of the pathogen was consistent with that described in previous reports $(24,38,45)$. Our preliminary comparison of root colonization by bv 2 and 3 strains was in agreement with the results by Orozco-Miranda et al. (30), who had already reported that bv3 strains were better root colonizers than those of bvs 1 and 2 in several plant species.

In potato plants, specific uidA staining clearly illustrated that root extremities and lateral root emerging sites were preferably colonized by the pathogen, as previously described in tomato roots, probably due to chemotaxis of $R$. solanacearum to root exudates $(45,48)$. Moreover, the endodermis is not yet fully differentiated at these sites and, consequently these root cracks constitute potential points of vascular cylinder infection, as already described in tomato plants (45). In inner plant tissues of potato roots and stems, our results confirmed that the xylem bundles and some parts in the cortex were invaded as illustrated elsewhere $(24,38)$. Tubers were also infected, exhibiting abundant bacterial ooze in the vascular ring as already reported $(24,38)$. We clearly demonstrated that eyes and stolon heel ends were the main entrance sites as previously suggested (24). No differences were observed between cvs. Désirée and Spunta with respect to the histological localization of the pathogen, although bacterial colonization in Spunta took longer to occur.

In bittersweet nightshade plants, blue uidA staining was observed in xylem of roots and collars, and also in the root cortex, although in most cases the pathogen was not isolated from the middle part of the stem. The presence of the bacterium in the lower parts of the stem but not in upper levels of the plant might be related to the presence of tyloses, microscopically visualized in vascular tissues, which would be limiting bacterial spread as a mechanism of plant defense in response to infection by $R$. solanacearum $(18,24,38)$. Our results confirm the general statement that bittersweet nightshade is a symptomless carrier of $R$. solanacearum $(11,22,25,31,39)$, although wilting has occasionally been reported (47).

The other plant species and cultivars were classified in three groups under the evaluated conditions: (i) susceptible hosts, (ii) tolerant hosts, and (iii) nonhost plants. The first two groups encompass plants which are invaded by high densities of the pathogen in xylem elements at the root level, while invasion of xylem at the middle part of the stem is heavy in susceptible plants and strongly limited in tolerant plants $(33,44)$. The last group refers to nonhost plants and includes species in which no xylem invasion was observed, though some external contamination of the rhizoplane and rare cortical infection pockets may occur.

The first group consists of the susceptible hosts. In forage cabbage cv. Proteor, the $\beta$-glucuronidase-expressing strain IPO1609 colonized root cortex and xylem and lower parts of stems and was isolated from middle part of stems in all analyzed plants. In contrast, in cabbage cv. Quintal d'Alsace and curly endive cv. 
Rida Doble de Verano, uidA expression was not observed in root xylem and, with respect to root cortex, it was negative for this cultivar of cabbage but positive for curly endive, whereas the specific blue staining was frequently visualized in cortex and xylem from the lower part of stems, and isolations were positive in all plants. Prior to bacterial multiplication in planta, low numbers of bacteria in roots and lower parts of stems were probably present but undetected by GUS activity assays. Consequently, all these plants should be considered susceptible to invasion by the tested strain of $R$. solanacearum R3 bv 2 and must be avoided in a crop rotation scheme. It has already been mentioned that curly endive may host $R$. solanacearum bvs 1 and 3, and exhibit symptoms of the disease (29).

The second group consists of the tolerant hosts. In cabbage cv. Virtudes and rutabaga cvs. Champion and Whilemsburger, specific uidA staining of inner plant tissues was observed in xylem vessels in roots or in low parts of stems in only a few individuals, and isolations from the middle part of stems were always negative. The related crop cauliflower (Brassica oleraceae cv. Capitata) has already been recognized as a tolerant host for $R$. solanacearum bvs 1 and 3 (29) and in field trials (41). B. oleraceae L. has been suggested as a potential biofumigant to reduce $R$. solanacearum bv3 populations in soil, though with limited success (6). In general, Brassicaceae plants have been considered hosts of $R$. solanacearum and are not recommended as a rotation crop $(3,4)$.

In kidney bean cv. Coco blanc, also a tolerant host, under axenic conditions an uidA expression was visualized both in xylem and cortex in most analyzed plants, while in nonaxenic peat mix just one individual was contaminated. Consequently, this cultivar should not be considered in crop rotation systems. Likewise, Katafiire et al. (23) (2005) reported that beans as a rotation crop were not as effective as cereals in reducing bacterial wilt incidence in the field (23). Phaseolus vulgaris L. has been recognized as a host for $R$. solanacearum, but not for bv2 (15). It has been reviewed either as a symptomless carrier for bv3 of $R$. solanacearum $(21)$, or as a host for bv3 $(9,21,29)$ and also for bv1 (29) and bv4 (21). These conflicting results are probably due to the use of cultivars displaying different susceptibility or of strains from different bvs or with variable levels of aggressiveness.

The third group consists of the nonhosts. In barley cv. Cork, black radish cv. Gros Long d'Hiver, fiber flax cv. Hermès, field bean cv. Maya, field pea cv. Solara, horseradish, maize cv. Symphony, and zucchini cv. Virginia, the specific uidA staining was only observed in some root cortex areas for some of the plant species, but never in inner root or stem tissues. In maize roots, intercellular infection pockets were microscopically visualized for $R$. solanacearum R3 bv2 and R1 bv3, although they were more developed by R1 bv3. The latter results support once again the statement that bv 3 strains can be better root colonizers of some species than bv2 strains (30). Interestingly, both bvs behaved in maize similarly to a nonpathogenic mutant of $R$. solanacearum in tomato (45), indicating that a similar incompatible hostbacterium combination could lead to the formation of restricted cortical infection pockets. Positive isolations of the pathogen were correlated with either root cortex infection or external epidermal presence of the $\beta$-glucuronidase-expressing derivative. In barley, intense uidA staining was visualized between the leaves, although the bacterium did not enter the plant. Typical sheath structure of Monocotyledoneae, with leaves inserted into each other, may constitute a protecting shelter for the bacterium, from where it can be isolated, as it was also found in maize. Likewise, in black radish, fiber flax, field bean, field pea, horseradish, and zucchini, a rough surface in the lower part of the stem seems to provide a shelter for the bacterium in highly contaminated plants. All these shelters might favor $R$. solanacearum survival, and tests should be performed under field conditions to know whether this bacterium can persist in them, acting as reservoirs in the absence of a host. That should be taken into account when selecting rotation crops, at least in humid areas. One report found that $R$. solanacearum could infect maize roots at a low frequency and that the infection remained localized (17). However, maize and other Gramineae have been successfully used to reduce bacterial wilt in a crop rotation system $(23,46)$, depending on the level of $R$. solanacearum infestation in soil (27).

In alfalfa cvs. Gea R1 and Symphonie, carrot cvs. Nantaise and Tempo, celery cv. Istar, colocynth, and fennel cv. Doux de Florence, no uidA staining by the derivative was observed in inner root or stem plant tissues, although the IPO-1609-Gus was detected on the surface of the roots in these alfalfa, carrot, celery, and fennel cultivars. Presence of $R$. solanacearum cells on the surface of roots indicates either that root infection was weak and undetected, or points to an actual inability to infect the latter plants. In a crop rotation system, carrots were not as effective as cereals in reducing bacterial wilt incidence (23), and it has been reported that $R$. solanacearum bvs 1 and 3 , but not bv 2 could colonize carrot root surfaces (29). Fennel was reviewed as a host without any reference to the bvs involved (21). To our knowledge, alfalfa, celery, or colocynth, which were nonhost plants according to our criteria, had not been previously tested to assess their resistance to $R$. solanacearum $\mathrm{R} 3$ bv 2 .

In this work, the variability of results within a plant family was remarkable. Plant species belonging to Brassicaceae were either susceptible, tolerant, or nonhost for the $\beta$-glucuronidase-expressing derivative of $R$. solanacearum R3 bv2, while those belonging to Leguminosae were either tolerant or nonhosts. Even for a single plant species the results will probably depend on the plant cultivar and/or the $R$. solanacearum bv, and within each bv on the aggressiveness of each strain. For this reason it would be advisable to address the host range of the $R$. solanacearum species complex not as a general statement but as a concept which is adapted to a geographical region with its own specific native strains and crops.

The methodology applied in this work, based upon a rapid and simple examination of a great many plant segments embedded into a GUS reactive agar, proved easy to use. It enabled us to preliminarily classify the plant species as susceptible hosts, tolerant hosts, or nonhosts for the bv2 of the pathogen, on the basis of histological localization in planta. On one hand, results pointed out some plant species and cultivars to be susceptible or tolerant for $R$. solanacearum R3 bv2, which presumably should be avoided as rotation crops. On the other hand, several candidates as nonhost plant species and cultivars were suggested, although some of them could be reservoirs of the pathogen under particular conditions. All these candidates should be tested in open-field trials prior to be utilized for rotation schemes aimed at a successful prevention of bacterial wilt damages and spread.

\section{ACKNOWLEDGMENTS}

B. Álvarez thanks the Marie Curie Foundation for a Marie Curie Fellowship at the IFR40 in Toulouse (France) and the Instituto Valenciano de Investigaciones Agrarias for a predoctoral grant. We thank S. Poussier for providing the $\beta$-glucuronidase-expressing IPO-1609 strain 1.3; the French Federation for Potato for sending Spunta and Désirée potato axenic seedlings; L. Penya, A. Urbaneja, and P. Lemos for technical advice; and F. Barraclough for the English language revision. This work was funded by the European contract QLK3-CT-2000-01598 acronym "Potatocontrol".

\section{LITERATURE CITED}

1. Akiew, E., and Trevorrow, P. R. 1994. Management of bacterial wilt of tobacco. Pages 179-198 in: Bacterial Wilt: The Disease and Its Causative Agent, Pseudomonas solanacearum. CAB International, Wallingford, UK.

2. Anonymous. 1998. Council Directive 98/57/EC of 20 July 1998 on the control of Ralstonia solanacearum (Smith) Yabuuchi et al. Off. J. Eur. Communities L235:1-39. 
3. Anonymous. 2000. Council Directive 2000/29/EC of 8 May 2000 on protective measures against the introduction into the Community of organisms harmful to plants or plant products and against their spread within the Community. Off. J. Eur. Communities L169:1-112.

4. Anonymous. 2006. Commission Directive 2006/63/EC of 14 July 2006: Amending Annexes II to VII to Council Directive 98/57/EC on the control of Ralstonia solanacearum (Smith) Yabuuchi et al. Off. J. Eur. Communities L206:36-106.

5. Araud-Razou, I., Vasse, J., Montrozier, H., Etchebar, C., and Trigalet, A. 1998. Detection and visualization of the major acidic exopolysaccharide of Ralstonia solanacearum and its role in tomato root infection and vascular colonization. Eur. J. Plant Pathol. 104:795-809.

6. Arthy, J. R., Akiew, E. B., Kirkegaard, J. A., and Trevorrow, P. R. 2005. Using Brassica spp. as biofumigants to reduce the population of Ralstonia solanacearum. Pages 159-165 in: Bacterial Wilt Disease and the Ralstonia solanacearum Species Complex. American Phytopathological Society, St. Paul, MN.

7. Boucher, C., Barberis, P., Trigalet, A., and Démery, D. 1985. Transposon mutagenesis of Pseudomonas solanacearum: Isolation of Tn5-induced avirulent mutants. J. Gen. Microbiol. 131:2449-2457.

8. Caruso, P., Bertolini, E., Cambra, M., and López, M. M. 2003. A new and sensitive Co-operational polymerase chain reaction for rapid detection of Ralstonia solanacearum in water. J. Microbiol. Methods 55:257-272.

9. Elphinstone, J. G. 2005. The current bacterial wilt situation: A global overview. Pages 9-28 in: Bacterial Wilt Disease and the Ralstonia solanacearum Species Complex. American Phytopathological Society, St. Paul, MN.

10. Elphinstone, J. G., Hennessy, J., Wilson, J. K., and Stead, D. E. 1996. Sensitivity of different methods for the detection of Ralstonia solanacearum in potato tuber extracts. EPPO Bull. 26:663-678.

11. Elphinstone, J. G., Stanford, H., and Stead, D. E. 1998. Survival and transmission of Ralstonia solanacearum in aquatic plants of Solanum dulcamara and associated surface water in England. EPPO Bull. 28:93-94.

12. Etchebar, C., Trigalet-Démery, D., Gijsegem, F. V., Vasse, J., and Trigalet, A. 1998. Xylem colonization by an HrcV- mutant of Ralstonia solanacearum is a key factor for the efficient biological control of tomato bacterial wilt. Mol. Plant-Microbe Interact. 11:869-877.

13. Fegan, M., and Prior, P. 2005. How complex is the "Ralstonia solanacearum species complex?" Pages 449-461 in: Bacterial Wilt Disease and the Ralstonia solanacearum Species Complex. American Phytopathological Society, St. Paul, MN.

14. French, E. R. 1994. Strategies for integrated control of bacterial wilt of potatoes. Pages 199-207 in: Bacterial Wilt: The Disease and Its Causative Agent, Pseudomonas solanacearum. CAB International, Wallingford, UK.

15. Girard, J. C., Nicole, J. F., Chéron, J. J., Gaubiac, A. M., Huvier, O., Oudard, B., and Suzor, H. 1993. Bacterial wilt due to Pseudomonas solanacearum in Réunion. Pages 343-347 in: Bacterial Wilt. General Situation and Current Research. Proc. Int. Conf., ACIAR, Canberra.

16. Graham, J., Jones, D. A., and Lloyd, A. B. 1979. Survival of Pseudomonas solanacearum race 3 in plant debris and in latently infected potato tubers. Phytopathology 69:1100-1103.

17. Granada, G. A., and Sequeira, L. 1983. Survival of Pseudomonas solanacearum in soil, rhizosphere, and plant roots. Can. J. Microbiol. 29:433-440.

18. Grimault, V., Gelie, B., Lemattre, M., Prior, P., and Schmit, J. 1994. Comparative histology of resistant and susceptible tomato cultivars infected by Pseudomonas solanacearum. Physiol. Mol. Plant Pathol. 44:105-123.

19. Grimault, V., and Prior, P. 1993. Bacterial wilt resistance in tomato associated with tolerance of vascular tissues to Pseudomonas solanacearum. Plant Pathol. 42:589-594.

20. Hayward, A. C. 1991. Biology and epidemiology of bacterial wilt caused by Pseudomonas solanacearum. Annu. Rev. Phytopathol. 29:65-87.

21. Hayward, A. C. 1994. The hosts of Pseudomonas solanacearum. Pages 924 in: Bacterial Wilt: The Disease and Its Causative Agent, Pseudomonas solanacearum. CAB International, Wallingford, UK

22. Janse, J. D. 1996. Potato brown rot in western Europe-History, present occurrence and some remarks on possible origin, epidemiology and control strategies. EPPO Bull. 26:679-695.

23. Katafiire, M., Adipala, E., Lemaga, B., Olanya, M., El-Bedewy, R., and Ewell, P. 2005. Management of bacterial wilt of potato using one-season rotation crops in Southwestern Uganda. Pages 197-203 in: Bacterial Wilt Disease and the Ralstonia solanacearum Species Complex. American Phytopathological Society, St. Paul, MN.

24. Kelman, A. 1953. The bacterial wilt caused by Pseudomonas solanacearum. A literature review and bibliography. North Carolina State College, $\mathrm{NC}$

25. Kempenaar, C., Groeneveld, R. M. W., Lotz, L. A. P., Wenneker, M., and Janse, J. D. 1998. Ecology and control of Solanum dulcamara in relation to brown rot. Gewasbescherming 29:119-123.
26. Lelliot, R. A., and Stead, D. E. 1987. Methods for the diagnosis of bacterial diseases of plants. Page 216 in: Methods in Plant Pathology, vol. 2. Blackwell Scientific Publications, Oxford.

27. Lemaga, B., Kanzikwera, R., Kakuhenzire, R., Hakiza, J. J., and Manzi, G. 2001. The effect of crop rotation on bacterial wilt incidence and potato tuber yield. Afr. Crop Sci. J. 9:257-266.

28. López, M. M., and Biosca, E. G. 2005. Potato bacterial wilt management: New prospects for an old problem. Pages 205-224 in: Bacterial Wilt Disease and the Ralstonia solanacearum Species Complex. American Phytopathological Society, St. Paul, MN.

29. Melo, M. S., and Takatsu, A. 1997. Root colonization of non-susceptible hosts by Ralstonia solanacearum. Page 78 in: 2nd International Bacterial Wilt Symposium. Book of Abstracts. INRA-CIRAD-ORSTOM, Guadeloupe, France.

30. Orozco-Miranda, E. F., Takatsu, A., and Uesugi, C. H. 2004. Colonization of the roots of weed cultivated in vitro and in pots by Ralstonia solanacearum, biovars 1, 2 and 3. Fitopatol. Bras. 29:121-127.

31. Persson, P. 1998. Successful eradication of Ralstonia solanacearum from Sweden. EPPO Bull. 28:113-119.

32. Poussier, S., Thoquet, P., Trigalet-Démery, D., Barthet, S., Meyer, D., Arlat, M., and Trigalet, A. 2003. Host plant-dependent phenotypic reversion of Ralstonia solanacearum from non-pathogenic to pathogenic forms via alterations in the phcA gene. Mol. Microbiol. 49:991-1003.

33. Prior, P., Grimault, V., and Schmit, J. 1994. Resistance to bacterial wilt (Pseudomonas solanacearum) in tomato: Present status and prospects. Pages 209-223 in: Bacterial Wilt: The Disease and Its Causative Agent, Pseudomonas solanacearum. CAB International, Wallingford, UK.

34. Rahman, M. A., Abdullah, H., and Vanhaecke, M. 1999. Histopathology of susceptible and resistant Capsicum annuиm cultivars infected with Ralstonia solanacearum. J. Phytopathol. 147:129-140.

35. Schonfeld, J., Heuer, H., van Elsas, J. D., and Smalla, K. 2003. Specific and sensitive detection of Ralstonia solanacearum in soil on the basis of PCR amplification of fliC fragments. Appl. Environ. Microbiol. 69:72487256.

36. Seal, S. E., Jackson, L. A., Young, J. P. W., and Daniels, M. J. 1993. Differentiation of Pseudomonas solanacearum, P. syzygii, P. picketti and the blood disease bacterium by partial 16S rRNA sequencing: construction of oligonucleotide primers for sensitive detection by polymerase chain reaction. J. Gen. Microbiol. 139:1587-1594.

37. Sharma, S., and Signer, E. 1990. Temporal and spatial regulation of the symbiotic genes of Rhizobium meliloti in planta revealed by transposon Tn5-gusA. Gene Dev. 4:344-356.

38. Smith, E. F. 1920. The brown rot of Solanaceae. Pages 177-201 in: Bacterial Diseases of Plants. Saunders Company, Philadelphia.

39. Stead, D. E., Elphinstone, J. G., and Pemberton, A. W. 1996. Potato brown rot in Europe. Brighton Crop Protection Conference: Pests and Diseases 1996 Vol. 3. Proc. Int. Conf., Brighton, UK.

40. Swanson, J. K., Yao, J., Tans-Kersten, J., and Allen, C. 2005. Behaviour of Ralstonia solanacearum race 3 biovar 2 during latent and active infection of geranium. Phytopathology 95:136-143.

41. Terblanche, J. 2002. The use of a biologically active rotation crop for the suppression of Ralstonia solanacearum in soils used for tobacco production. Bacterial Wilt Newslett. 17:8-9.

42. Tusiime, G., Adipala, E., Opio, F., and Bhagsari, A. S. 1998. Weeds as latent hosts of Ralstonia solanacearum in Highland Uganda: Implications to development of an integrated control package for bacterial wilt. Pages 413-419 in: Bacterial Wilt Disease. Molecular and Ecological Aspects. Springer-Verlag, Berlin

43. van Elsas, J. D., Kastelein, P., de Vries, P. M., and van Overbeek L. S. 2001. Effects of ecological factors on the survival and physiology of Ralstonia solanacearum biovar 2 in irrigation water. Can. J. Microbiol. 47:842-854.

44. Vasse, J., Danoun, S., and Trigalet, A. 2005. Microscopic studies of root infection in resistant tomato cultivar Hawaii 7996. Pages 285-291 in: Bacterial Wilt Disease and the Ralstonia solanacearum Species Complex. American Phytopathological Society, St. Paul, MN.

45. Vasse, J., Frey, P., and Trigalet, A. 1995. Microscopic studies of intercellular infection and protoxylem invasion of tomato roots by Pseudomonas solanacearum. Mol. Plant-Microbe Interact. 8:241-251.

46. Verma, R. K., and Shekhawat, G. S. 1991. Effect of crop rotation and chemical soil treatment on bacterial wilt of potato. Indian Phytopathol. $44 \cdot 5-8$

47. Wenneker, M., Verdel, M. S. W., Groeneveld, R. M. W., Kempenaar, C., Beuningen, A. R. V., and Janse, J. D. 1999. Ralstonia (Pseudomonas) solanacearum race 3 (biovar 2) in surface water and natural weed hosts: First report on stinging nettle (Urtica dioica). Eur. J. Plant Pathol. 105:307-315.

48. Yao, J., and Allen, C. 2006. Chemotaxis is required for virulence and competitive fitness of the bacterial wilt pathogen Ralstonia solanacearum. J. Bacteriol. 188:3697-3708. 